\title{
Firm's Performance And Top Management Characteristics In Indonesia
}

\author{
H. Herri, Andalas University, Indonesia
}

\begin{abstract}
Studies on the impact of management characteristics on the performance of companies has attracted many researchers. This topic has received a lot of attention after articles by Hambrick and Mason (1984). In the context of Indonesia, this topic has not received much attention. It is the intention of this paper to bridge this gap by developing the framework and testing a hypothesis. The samples for this study comprised of 117 manufacturing firms listed in the Directory of Indonesian Manufacturing Firms. This study confirmed that locus of control, one of the personality characteristics has a relationship with company performance. Other personality and demography characteristics however did not have any impact on the performance of the companies studied. This paper also discussed the implications of the findings and suggestions for future research.
\end{abstract}

Keywords: strategic leadership; firms performance; developing countries

\section{INTRODUCTION}

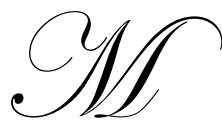

any questions have been raised with regard to the factors that contribute to the performance of organization. In the viewpoint of strategic leadership, organizational success has a close relationship with the characteristics of the top managers (Finkelstein, Hambrick and Cannella, Jr, 2009: Sebaa, James and Cornelius, 2009). Managers who are risk takers and creative will formulate more and risk competitive strategy compared to managers who are not (Chandler, 1962). Child (1974) and Govindarajan (1989) in their researches proposed that the relationship exists

However, not all researchers agree on the relationship between the manager's characteristics and the organizational performance, among them are Nahavandi and Malekzadeh (1993) as well as Hitt, Ireland, and Hoskisson (2007). They argued that managers are not important in relation to the performance of organization. The goal of this research is to find out whether the relationship between the characteristics of top managers and the performance of the Indonesian companies exists.

\section{LITERATURE REVIEW}

\subsection{Manager In Organization}

One key person responsible for setting up the way to compete is people on top of the organization (Finkelstein, Hambrick, and Cannella, 2009). However not much attention has been given to top manager involvement in developing the way to compete even though many previous studies had revealed the roles of executives in the organization (Zéghal and Gouiaa, 2009: Li and Tan, 2009).

Hambrick and Mason (1984) introduced the concept of the strategic leadership or the upper echelon theory. They argued that companies are the reflection of their top leaders, the way the companies compete in the market place is mainly influenced by their leaders' characteristics such as their demography, personality, functional background and interest to the firms (Bhagat and Bolton 2009). 


\subsection{Top Manager And Firm Performance}

There is no one correct answer as to the factors that determined firms' performance due to the complexities of the business environment. Some of the factors that influence performance are countable, some are uncountable, some are within and outside the firms' control while some are universal or contingent (Child,1974).

\subsection{Characteristics Of Personality Traits And Firm Performance}

Locus of control and risk taker are some of the manager's characteristics that have been known to have relationship to performance. A person who has internal locus of control tend to think that everything they achieved is a result of their efforts. According to Rotter (1996) people with internal locus of control are more creative than people with external locus of control. Boone De Brabander and Johan (2000) added to this argument that based on the strategic leadership theory especially the upper echelon theory, firms managed by manager with internal locus of control usually exhibited higher performance.

People who like challenges are close to being a risk taker, managers who like taking risks tend to be creative in solving problems compared to those who are not Nahavandi et al., 1992). Manager who are risk taker use more differentiation in their product and made innovation that has positive impact on performance (Hutlink and Robben, 1999; Fries \& Smith, 2004).

\subsection{Background Of Functional Characteristics, Demography And Firm Achievement}

Demography characteristics related to performance are age, education and manager functional background (Kitchell, 1997). However, Lieberson and O'Connors (1972) concluded that the manager is not a significant contributor to the firm's performance.

\subsection{Performance}

The performance indicator usually used in strategic management research is economic performance, for example, sales growth profitability, return on assets and return on equity. Some research used sales growth as the indicator of growth (Chakravarti, \& Mahmood, 2007). The weakness of using these indicators is that it has depreciation, however it is easier to collect and most firms in growing industries used this kind of goals.

\subsection{Theoretical Framework}

Figure 1 is a model that explained the relationship between manager characteristics and firms performance based on the literature review in the previous section.

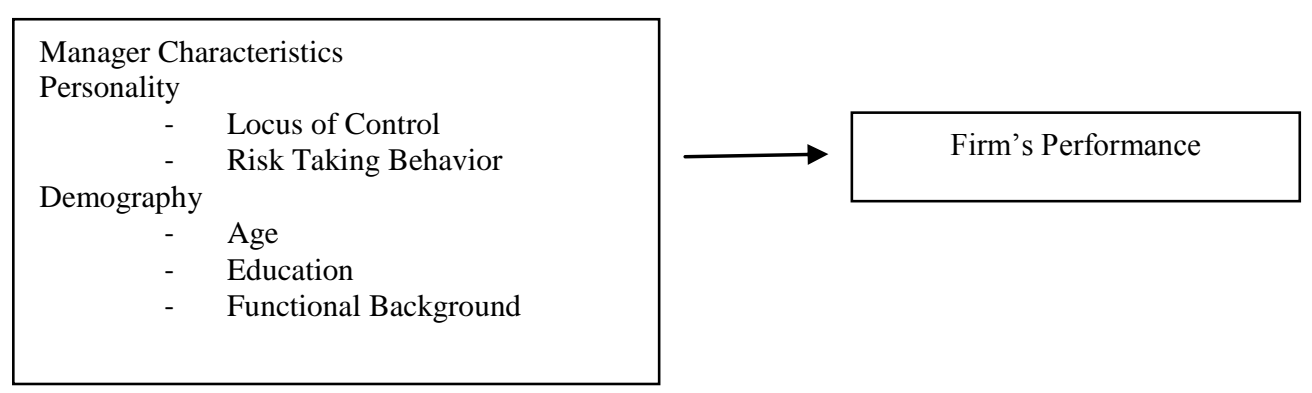

Figure 1: A Model Related Between Manager Characteristics And Firms Performance 


\subsection{Hypothesis}

This research tested the hypothesis; do manager characteristics have significant influence on the firms' performance of manufacturing firms in Indonesia.

\section{RESEARCH METHOD}

Unit of analysis of the research large manufacturing firms listed in The Directory of Manufacturing Firms in Indonesia. The number of samples are 117 companies and the respondents top managers.

\subsection{Sample Selection}

The following criteria were used for the selection of companies as samples for this research. Firstly, the firm has more than 200 employees/workers, secondly, it has been in the market for a minimum of 5 years and thirdly there was no top manager at least 2 years at the time this research is conducted.

\subsection{Questionnaire}

The questionnaire was the instrument used for gather primary data and to measure the research variables. Most of the questions had previously been used by other researchers. The questionnaire consists of three main parts; the first part dealt with the characteristics of the company, followed by the characteristics of the managers and lastly questions to measure the variables of the study.

\subsection{Measurements}

\subsection{Functional Background}

Functional background was measured as nominal variable and will be grouped as functional background and throughput background. Managers who were classified under output functional background has experience in Marketing, Selling and Product Development. Those who has experience besides those listed were classified in the throughput functional background (Hambrick \& Mason, 1984; Miles \& Snow, 1978; Schoenecker et al., 1995 and Thomas \& Ramaswamy, 1996).

\subsection{Age}

Age was measured by the current age of the manager at the time the research was conducted. There were three age groups. Respondents in the age range of more than 55 years were classified as old, those between 40 years and 55 years were classified as middle and those in the 40 years old age group were categorized as young.

\subsection{Education}

The education variable was measured by the number of years of formal education received by the respondents. This measurement is in line with that used by Hambrick and Mason (1984).

\subsection{Personality Characteristics}

Locus of Control, measurement for locus of control is based on the works of Nahavandi (1997) and Rotter (1996). To measure this variable, the respondents were given 16 questions that consist of statement A and B; they were to choose statement $\mathrm{A}$ or $\mathrm{B}$ which was relevant to their perspective. A score will given; if the respondent answer A, the score is 1 (internal); on the other hand if the answer is B the score is 0 (external). The score for each respondent will be calculated. Respondents will be classified based on the score; the higher the score the higher the internal locus of control of the respondent will be. 
Risk taking Behavior measurement of this variables followed work of Nahavandi (1997), there were five questions which were used to measure risk taking behavior, using Likert Scale with (1) indicating disagree and (7) extremely agree. The questions focus on the respondents perspectives about what job they like and their perception about change. Risk taking behavior of each respondent is based on the average score of the five questions given. A higher score means that the respondent belongs to the high risk taking behavior.

\subsection{Firms Performance}

ROA and sales growth were used to measure the firm's performance. Firm's return on assets was measured by comparing earnings after taxes to total assets for 5 years. Sales growth was also measured by the average sales growth for 5 years.

\section{RESULT OF THE STUDY}

\subsection{Analysis}

The summary of the firms' profile is shown in Table 1. From the 117 samples, 66 firms produced cement, plastics, pulp and iron. Another 51 firms (43.6\%) produced consumer products; textiles, food, beverages and cigarettes.

The age of the firms ranges between 5 years to 82 years, with an average of 23 years and a standard deviation of 14 years. The large firms employed 8970 workers while the smallest one has 200 workers; with an average of 1736 workers and a standard deviation of 1769 workers.

Table 1: Firm's Profile As Research Samples

\begin{tabular}{|c|c|c|c|c|c|}
\hline \multicolumn{2}{|c|}{ Firm's Profile } & \multirow{2}{*}{$\begin{array}{c}\text { Total } \\
66\end{array}$} & \multirow{2}{*}{$\begin{array}{c}\text { Percentage } \\
56,4\end{array}$} & \multirow{3}{*}{$\begin{array}{c}\text { Average } \\
-\end{array}$} & \multirow{3}{*}{$\begin{array}{c}\begin{array}{r}\text { Standard } \\
\text { deviation }\end{array} \\
-\end{array}$} \\
\hline \multirow{2}{*}{ Kinds of work } & Industry product & & & & \\
\hline & Consumer product & 51 & 43,6 & & \\
\hline \multirow{4}{*}{ Age } & $<10$ & 31 & 26,5 & \multirow{4}{*}{23 (years) } & \multirow{4}{*}{14} \\
\hline & $10-24$ & 46 & 39,3 & & \\
\hline & $25-54$ & 35 & 29,9 & & \\
\hline & $>54$ & 5 & 4,3 & & \\
\hline
\end{tabular}

\subsection{The Firm's Performance}

The firm's performance was measured by sales growth and returns. The average total sales and sales growth for the last 5 years is on the increase. Table 2 shows the average total sales increase for each year. The minimum average total sales is $-19 \%$ and the maximum is $75.12 \%$.

The average return on assets in 5 years is shown in Table 3. The average return on assets has a minimum score of $5.39 \%$ and the maximum score of $7.11 \%$. If we were to pay much attention to individual score for at least 5 years, the highest score was $29.33 \%$ and the lowest was $-9.62 \%$; with the standard deviation of $6.94 \%$ and an average of $6.60 \%$.

Table 2: Average Of Total Sales And Average Of Sales Growth Firms

\begin{tabular}{|l|c|c|c|c|c|}
\hline & \multicolumn{5}{|c|}{ Years of Research } \\
\cline { 2 - 6 } & First & Second & Third & Fourth & Fifth \\
\hline $\begin{array}{l}\text { Average of Sales } \\
\text { (million Rp) }\end{array}$ & 274,545 & 372,005 & 452,305 & 469,082 & 623,715 \\
\hline $\begin{array}{l}\text { Average of totally sales } \\
\text { growth (million Rp) }\end{array}$ & - & 16.40 & 10.26 & 1.84 & 15.31 \\
\hline
\end{tabular}




\subsection{Managers' Characteristics}

Table 3 below describe manager's characteristics of the research samples. The youngest top manager is 33 years old while the oldest is 73 years old. The average age stands at 51 years old. Generally the top managers fall into the middle age category (44- 55 years old).

Table 3: Characteristics Of Firm's Top Manager

\begin{tabular}{|c|c|c|c|c|c|}
\hline Manager's Profile & Classification & Total & Percentage & Average & Standard Deviation \\
\hline \multirow[t]{3}{*}{ Age } & $<40$ & 16 & 13.7 & \multirow[t]{3}{*}{51} & \multirow[t]{3}{*}{7.6} \\
\hline & $40-55$ & 68 & 58.1 & & \\
\hline & $>55$ & 33 & 28.2 & & \\
\hline \multirow[t]{3}{*}{ Education } & SLTA & 7 & 6.0 & & \\
\hline & Diploma & 87 & 74.3 & & \\
\hline & Academician degree & 23 & 19.7 & & \\
\hline \multirow[t]{3}{*}{ Tenure } & $<5$ & 12 & 10.2 & \multirow[t]{3}{*}{8.6} & \multirow[t]{3}{*}{4.6} \\
\hline & $5-10$ & 74 & 63.2 & & \\
\hline & $>10$ & 31 & 25.6 & & \\
\hline \multirow{2}{*}{$\begin{array}{c}\text { Functional } \\
\text { Background }\end{array}$} & Output & 65 & 57.5 & & \\
\hline & Throughput & 48 & 42.5 & & \\
\hline \multirow[t]{7}{*}{ Locus of Control } & 2 & 1 & 9 & \multirow[t]{7}{*}{5.9} & \multirow[t]{7}{*}{1.1} \\
\hline & 3 & 2 & 1.7 & & \\
\hline & 4 & 13 & 11.1 & & \\
\hline & 5 & 19 & 16.2 & & \\
\hline & 6 & 44 & 37.6 & & \\
\hline & 7 & 36 & 30.8 & & \\
\hline & 8 & 2 & 1.8 & & \\
\hline $\begin{array}{c}\text { Risk Taking } \\
\text { Behavior }\end{array}$ & & & & 5.6 & 0.7 \\
\hline
\end{tabular}

In terms of education the top managers, the highest qualification was a university degree while the lowest graduated from senior high school. The majority of the top manager graduated from high school; with an average education period of 16 years or an academic degree; a minimum of 12 years and a maximum of 21 years. It has a standard deviation of 2.3. This figures shows that managers in Indonesia were an educated lot.

The average working experience of the top manager was 9.9 years, the minimum was 5 years while the maximum was 30 years. In general terms there is not much difference in terms of experience as $63.2 \%$ of the top managers held their job for more than 5 years; with an average of 8.6 years. The shortest period as top manager was 2 years and the longest 26 years.

From the samples, 64 or $57.5 \%$ of the top managers represent those with the output background while 48 or $42.5 \%$ are of the throughput functional background. This shows that a top manager can be from both the output or throughput functional backgrounds.

The average score for locus of control is 5.85 and a median of 6 . From this distribution of locus of control scores, there are many respondents who had internal locus of control.

The validity test on the research variables concluded that the variables had relationship with each other; with a coefficient (r) between $0.4-0.7$; indicating that the data is valid. In addition the reliability test found Cronbach Alpha 0.64, showing a good reliability of each variable (Nunnaly,1967). The statistic descriptive to the risk taker questions was 5.6 with a standard deviation of 0.7.This indicated the high relativity common in risk taking characteristics. 


\subsection{Hypothesis Test}

The hypothesis test concluded that the top manager had influence on the firm's performance. This is shown by the regression analysis in Table 4 . In this table it is indicated that personality characteristics and top manager demography had significant influence on firm performance as measured by sales growth $(\mathrm{R} 2=12.3 \%, \mathrm{~F}=3, \mathrm{n}=$ $0.012)$; while another measured by ROA is not significant $(\mathrm{R} 2=8.7 \%, \mathrm{~F}=2.117, \mathrm{p}=0.069)$. We can thus conclude that the hypothesis is partially acceptable.

Partial test from the regression analysis found that the locus of control had significant relationship with performance that was measured by sales growth. In addition to that, functional background, level of education, age and risk taking behavior did not have any significant relationship to the performance.

Table 4: The Summary Of Regression Analysis Relationship

Between Top Manager's Characteristics To Firm's Performance

\begin{tabular}{|c|c|c|c|c|}
\hline \multirow{2}{*}{$\begin{array}{c}\text { Independent } \\
\text { Variable }\end{array}$} & \multicolumn{3}{|c|}{ ROA } & \multicolumn{3}{c|}{ Sales Growth } \\
\cline { 2 - 5 } & $\boldsymbol{\beta}$ score & Sig. & $\boldsymbol{\beta}$ score & Sig. \\
\cline { 2 - 5 } & 0.218 & $\mathbf{0 . 3 5}$ & 0.331 & $\mathbf{0 . 0 0 1}$ \\
\hline Locus of Control & -0.010 & 0.925 & 0.000 & 0.997 \\
\hline Level of Education & 0.136 & 0.227 & 0.018 & 0.686 \\
\hline Risk Taking & 0.107 & 0.316 & -0.073 & 0.483 \\
\hline Age & 0.020 & 0.859 & 0.016 & \multirow{2}{*}{$\mathbf{0 . 0 1 2}$} \\
\hline Functional Background & 0.087 & 0.069 & 0.123 & \\
\hline R2 & 2.117 & & 3.104 & \\
\hline
\end{tabular}

\section{FINDINGS}

This research indicated that there is a relationship between top manager's characteristics with firm's performance even though not all the variables had significant influence in the manufacturing industry in Indonesia. This different from that of other country where more than one variable has relationship. Between each independent variable only locus of control as one of the manager characteristics had significant relationship to firm's performance even though it is not the case with manager personality and demography.

The findings of this research especially on the relationship between locus of control and firm's performance is in line with that of other researchers; Boone et al, (2000), Kotey and Meredith, (1997) and Yusof (2001). This researcher argued that a manager who has internal locus of control will face business competition by implementing creative ways to improve firm's performance. Managers with internal locus of control will have the ability to develop unique ways to compete or would employ differentiation methods to outperform their competitors.

This research finding differs from that of Jaafar, Ramayah and Mohammad (2004); Mohamad and Sung (2009). Jaafar et., al (2004) did not find relationship between the locus of control to the firm's performance in the Malaysian Contractor's firm. They concluded that the firm's performance would be higher if the education level was high. The difference can be attributed to the sample frame. Jaafar et al, used samples where the education level is higher compared with this research; mostly senior high school graduates.

Other characteristics such as age, functional background, level of education and risk taking behavior had no relationship with the performance. It is also different from Friss and Smith (2004) that found a relationship between risk taking and company's performance.

\section{IMPLICATIONS}

There are some implications that can be drawn from the discussion. This research has expanded knowledge and understanding with regard to the study of upper echelons. It confirmed that model relationship between manager's 
characteristics to firm's performance of large companies in the developed countries may be applicable to a certain extent in developing countries. Moreover this research gave us some information on how to recruit new managers by taking into account their internal locus of control. Besides that we could also influence those who has external locus of control through education and training to become manager with internal locus of control.

\section{LIMITATIONS}

This research used industry samples from the manufacturing companies without distributing them into sub groups. In future perhaps wider samples should be used so that we can see the score per their sub-groups. This research also used firm's performance based on perspective instead of objective data gathered from financial report could be used.

\section{AUTHOR INFORMATION}

H. Herri is a Professor in Strategic Management, at Management of Department, Faculty of Economics, University of Andalas. Before joining Andalas University he worked at Regional Development Bank in Padang. His research interests include the areas of strategic leadership, human recourse management at small and medium enterprise. A part from teaching, he also conduct a consultant job and instructor for some trainings as well. Currently, he is a coordinator for University of Andalas Second Campus in Payakumbuh. E-mail: herri@ fekon.unand.ac.id

\section{REFERENCES}

1. Bhagat, Sanjai and Bolton, B, 2009, Manager Characteristics and Capital Structure: Theory and Evidence, Working Paper, JEL Classification Codes: G32, D92, D86.

2. Boone, C., De Brabander, Bert, and Witteloosteujn, van Arjen., 1996,CEO Locus of Control and Small Firm Performance : An integrative Framework and Empirical Test, Journal of Management Studied,33:5, September,367-399.

3. $\quad$ Chandler, A.D.Yr., 1962, Strategy and Structure, New York: Dubleday, Garden City.

4. Chakravarti, A., Singh, K., and Mahmood, I., 2007, Diversification and performance: Evidence from east Asian firms. Strategic Management Journal, 101-120.

5. Child, J, (1974), Managerial and Organizational Factors Associated with Company Performance, Part I, Journal of Management Studies, October, 175-189.

6. Finkelstein, S., and Hambrick, D and Cannella, Jr, A., A, 2009, Strategic Leadership: Theory and Research on Executives, Top Management Teams, and Boards, Oxford University Press.

7. Frilis L. B and Smitt E.vd. M, 2004, Are some fund managers better than others? Manager characteristics and fund performance, S. Afr. J. Bus. Manage. 35 (3), page: 31-40.

8. Hambrick, D.C., and Mason, P.A, 1984, Upper Echelons, The Organization as a Reflection of its Top Managers, Academy of Management Review, Vol. 9, 193-206.

9. Hitt, M.A, Ireland ,R.D.,\& Hoskisson ,R. E., 2007, Strategic Management: Competitiveness \& Globalization, Ed. 5, South Western College Publishing.

10. Hutlink Erik Jan and Robben, Henry S.J, 1999, Launch Strategy and new product performance: an empirical examination in the Netherlands, Journal of Product Innovation Management, Vol. 16, Issue 6, November, page 545-556.

11. Jaafar, Mastura, Ramayah,T and Mohammad Oesman, 2004,Owner/Manager Characteristics and Business Success: A study Among Malaysian Contractots, Working Paper, University Sains Malaysia.

12. Kitchell, M., 1997, CEO Characteristics and Technological Innovativeness: A Canadian Perspectives, Canadian Journal of Administrative Sciences, Vol. 14.2, 111-125.

13. Kotey,B., \& Meredith ,G.G., 1997, Relationship Among Owner/Manager Personal Values, Business Strategy and Enterprise Performance, Journal of Small Business Management, Vol. 35, 2, 37-63.

14. Lieberson, S., and O'Connor, J.E., 1972, Leadership and Organizational Performance: A Study of Large Corporations, American Sociological Review, Vol. 37, 2, 117-130.

15. Li Haitao, Zhang Xiaoyan, and Zhao Rui, 2009, Investing in Talents: Manager Characteristics and Hedge Fund Performances, working paper, University of Wisconsin, JEL: G23, G11, G12. 
16. Li, Yan and Tan Chuan Hoo, 2009, Aligning CIO Characteristics to Business Strategy: An Empirical Investigation. Proceedings of the 42nd Hawaii International Conference on System Sciences - 2009.

17. Lu, L., Wu, H. and Cooper, C. L, 1999. Perceived Work Stress and Locus of Control: A Combined Quantitative and Qualitative Approach, Research and Practice in Human Resource Management, 7 (1), page 1-15.

18. Miles, R. E. and Snow, C.C, 1978, Organizational Strategy, Structure and Process, New York: McGraw Hill Book Company.

19. Mohamad, H., M, and Sung, C., I, 2009, Variations in Performance in Chinese Small and Medium Enterprises. IJ MS 16 (1), 97-113.

20. Nahavandi, A. and Malekzadeh, A. R., 1993, Leadership Style in Strategy and Organization Performance: an Integral Approach, Journal of Management Studies, 3 May , 405-425.

21. Nahavandi. A., 1997. The Art and Science of Leadership, New York: Prentice Hall.

22. Nunnally, Jum C. 1967, Psychonometric Theory, McGraw Hill, New York.

23. Rotter, J., 1966, Generalized Expectancies for Internal Control versus External Control of Reinforcement, Psychological Monographs, whole no. 609.

24. Schoenecker, etl., 1995, Factors Affecting a Firm's Commitment to Innovation, Academy of Management Journal, Special Volume/Issues, 52-61.

25. Sebaa Ali Ahmed, Wallace, James and Cornelius, Nelarine, 2009, Managerial characteristics, strategy and performance in local government Measuring Business Excellence Volume: 13 Issue: 4 Page: 12 - 21.

26. Sharfman, M., 1998, On the Advisability of Using CEO's as the Sole Informant in Strategy Research, Journal of Managerial Issues, Fall, 10, 3, 373-392.

27. Smith, K.G., Guthrie, J.P. and Chen, M.J., 1989, Strategy, Size and Performance, Organizational Studies, $10(1), 63-84$.

28. Thomas, A.S., and Ramaswamy, K., 1994, Matching Managers To Strategy, An Investigation of Performance Implications and Boundary Conditions, Australian Journal of Management, Vol. 19.1, June 73-93.

29. Ung Ling Jen, 2003, The Project Manager's Personal Characteristics, Skill and Roles in Local Construction Industry, Unpublished Thesis, University Technology Malaysia.

30. Yusof, M.K, 2001.Locus of Control and Malaysian Entrepreneurship: A survey of literature. Proceeding in First Entrepreneurship and Small Business Conference in, Langkawi Malaysia.

31. Zéghal, Daniel and Gouiaa, Raef, 2009 The Effect of the Board of Directors' Characteristics on the Financing Strategies of French Companies, Journal of International Management Studies, Volume 4, Number 2, August, 1-11. 